\title{
The Influence of Personal Value on Entrepreneurship Intention
}

\author{
Dian Herdiana Utama ${ }^{1, *}$ Hari Mulyadi ${ }^{2,}$ Disman $^{3}$, Silmi $^{4}$
}

\author{
${ }^{1}$ Universitas Pendidikan Indonesia \\ ${ }^{2}$ Universitas Pendidikan Indonesia \\ ${ }^{3}$ Universitas Pendidikan Indonesia \\ ${ }^{4}$ Universitas Pendidikan Indonesia \\ *Corresponding author.Email: dhutama@upi.edu
}

\begin{abstract}
This study aims to determine the dimension of personal value towards a student at Kiansantang Vocational High School towards their intention in entrepreneurship. A cross-sectional through an explanatory survey method was used as the research design of this study. A questionnaire was used to collect data from 75 respondents of 12 th grader students of Kiansantang Vocational Highschool. The analysis technique was an explanatory technique using frequency distribution and path analysis. The results showed personal value (as exogen variable) simultaneously proved to be positive towards entrepreneurship intention. The results of personal value dimension self-direction showed a positive effect on entrepreneurship intention with a significant number and categorized as high.
\end{abstract}

Keywords: Entrepreneurship Intention, Personal Value.

\section{INTRODUCTION}

Entrepreneurship is a manifestation of human behavior in terms of creative development and motivation to create a better world [1] Entrepreneurship has been seen as the solution of discrepancy number of the labor force and the availability of the work field. According to McKinsey [2] in their report, WorkForce Transaction in a Time of Automation, the labor force trend affects the quality of education. Regarding today's condition, every worker needs to achieve at least a secondary education and practical skill to compete in the current market situation.

Regarding this, Vocational High School (VHS) in Indonesia developed as formal education developed with special curriculum refer to comply with the need of the industrial market and entrepreneur market [3]. According to Undang-Undang Sistem Nasional Tahun 2003 Pasal 15, a student in a vocational-based school is prepared to work on their respective field. Direktorat Pembinaan Kejuruan issue an entrepreneurship training for school program or known as Sekolah Perintis Wirausaha (SPW) based on Instruksi Presiden No. 9 Tahun 2016 about VHS revitalitaion on entrepreneurship field. SPW is a learning model for developing student skill set on entrepreneurship through the real experience of entrepreneurs learning in school subject Produk Kreatif dan Kewirausahaan (PKKWU) and digital communication simulation [4]. The purpose of SPW is to develop student intention and creativity in entrepreneurship beyond their vocational skill [5].

Kiansantang Vocational School is one of the Private Vocational Schools in Bandung orients in business and management. It also has entrepreneurship subjects (PKKWU) as compulsory subjects in schools. The form of organizing PKKWU subjects at SMK Kiansantang is done by dividing learning activities based on the grade level of students. In class $\mathrm{X}$ students in all areas of expertise study PKKWU in terms of theoretical course for one year of learning. In the second year, students in all fields of expertise practice in planning, producing goods, marketing goods, and making reports on sales within one year of learning. Whereas in the third year, students study entrepreneurship as an additional activity outside the subject area of expertise only (Source: Interview Teacher PKKWU Subject Coordinator, Ms. Winda October 2019).

Although PKKWU subjects have been delivered in such a way, the learning objectives of the subjects in enhancing the spirit of entrepreneurship have not been well implemented. According to Ms.Winda, it is known 
that most of the XII grade students who have completed two years of learning entrepreneurship theory and practice chose not to continue their business activities. Some reasons given by students according to Ms. Winda (Coordinator Teacher of PKKWU) are caused by not having capital, not having time to prepare goods (students have focused on preparing for the exam), and there is no enthusiasm to continue selling (no obligation is imposed for selling as in the previous year). The reasons for students not to continue their entrepreneurial practices in class XII are indicated as the low mental attitude of their entrepreneurship.

Ibrahim \& Essa (2019) explained that intention is someone's readiness to show behavior. Based on the dimensions of entrepreneurial intentions proposed by Bygrave [6], the low intentions of an entrepreneur are marked by a lack of confidence in oneself to control their life goals (locus of control). This statement is the same as the statement of PKKWU teacher, Ms. Winda regarding the reasons of the students in class XII namely, do not have the spirit to do entrepreneurial activities because there are no demands of value that must be met. The second factor is the ability to identify opportunities that are around and make decisions quickly (perceived opportunity). As well as dedication and endurance in achieving success and focus in utilizing the advantages that have (perseverance) which is indicated by the reasons of limited capital and time as the student promoted to XII grader.

Research on entrepreneurial intentions has been widely carried out. Broadly speaking, two main factors that drive the creation of entrepreneurial intentions, there are internal factors and external factors. Internal factors are the conditions or basic abilities possessed by individuals including commitment and determination [4], self-motivation [7], personality [8], individual values [9], personal values [10], and trust [11]. Meanwhile, external factors are situations surrounding individuals such as the social environment [12], family environment [13] role models [14], and education level [15].

Individual value can influence a person's perception of a behavior [16]. Values as abstract conceptions encouraging individuals to take attitude and evaluate behavior and events [17]. According to Moriano [18], entrepreneurs have higher specific characteristics than other workers in general and normative beliefs related to these activities. The congruency between personal values and normative beliefs in society will then increase one's intention towards entrepreneurship. Schwart [10]groups personal values related to individual skills in managing opportunities, there are achievement, stimulation, and self-direction.

This study aims to determine the influence of the personal value of XII grade students of SMK Kiansantang on entrepreneurial intention simultaneously and partially. In addition to getting a picture of the dominant and not dominant variables that influence student intention in entrepreneurship through direct and indirect path analysis. This research was conducted using two main theories, personal value theory from [10] and Bygrave's entrepreneurship intention theory [9]. The paradigm of this study is illustrated in Figure 1 below.

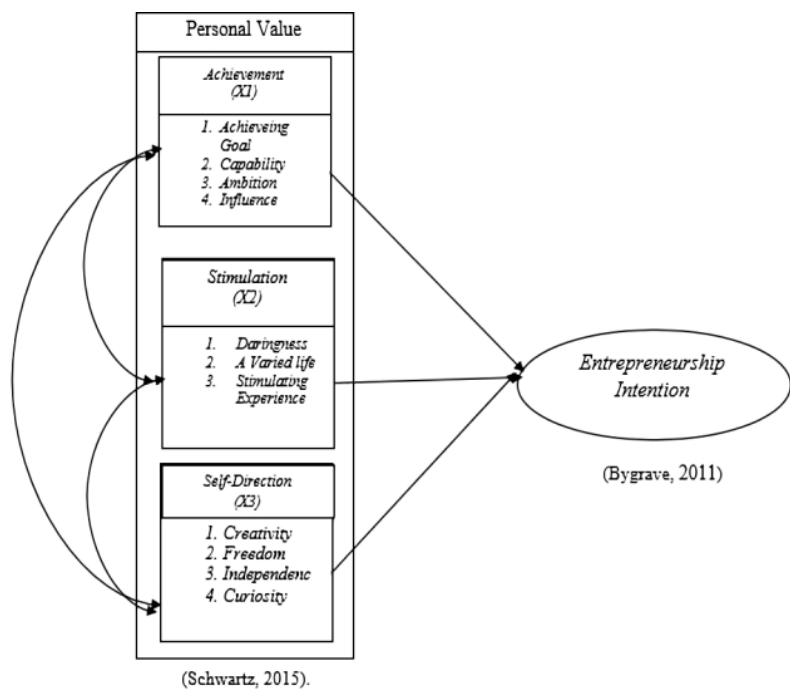

Figure 1 Research paradigm

\section{METHODS}

This study applied quantitative research as a method. According to [19] (2013), quantitative research aims to measure a phenomenon by using numerical data calculations and statistical test applications. In this study, the hypotheses were tested through data collection regarding achievement, self-direction, and stimulation of entrepreneurship intention in XII grade students of SMK Kiansantang with an analysis unit of 75 respondents taken using saturated samples. This research was conducted in less than one year in 2019 using the crosssectional method [20]. The data analysis technique was conducted through path analysis. [21] mentioned that path analysis is a multi-variant dependency data analysis method used to test asymmetric relationship hypotheses built based on the study of certain theories, which aim to determine the direct and indirect effects of a set of causative variables on the observed directly. The calculation of the results of the data is done using SPSS 24.0 for Windows.

\section{RESULTS AND DISCUSSION}

As stated by [22], the underlying assumption of the path analysis model is the correlation between variables. It is necessary to know in advance about the level of data normality. Moreover, the goal of the normality test is to find out whether the data generated in the field assume normal to be used in the path analysis model. Normality test is carried out using the Kolmogorov Smirnov test with the provisions of the test, if the data is $>0.05$ then 
the data is normal. Based on the test results it is known that the normality test value of the data in this study is 0.200 , meaning that the data obtained is normal so it is feasible to be analyzed by path analysis.

Simultaneously, the influence of personal value consisting of achievement, stimulation, and self-direction on entrepreneurship intention on 75 respondents using ANOVA calculations, it is known that the Fount value is 12,820 with a comparison on the Ftable value of 2.73 and a significance level of 0.00 . Based on these results it is known that simultaneously personal value has a positive and significant effect on entrepreneurship intention. More clearly, the ANOVA calculation table is explained in the following table 1.

Table 1. Simultaneous Test Results

\begin{tabular}{|c|l|c|c|c|c|c|}
\hline \multicolumn{7}{|c|}{ ANOVA } \\
\hline \multicolumn{2}{|c|}{ Model } & $\begin{array}{c}\text { Sum of } \\
\text { Squares }\end{array}$ & Df & $\begin{array}{c}\text { Mean } \\
\text { Square }\end{array}$ & F & Sig \\
\hline 1 & Regression & 2707.295 & 3 & 902.432 & 12.820 & $.000 \mathrm{~b}$ \\
\hline & Residual & 4997.692 & 71 & 70.390 & & \\
\hline & Total & 7704.987 & 74 & & & \\
\hline
\end{tabular}

The partial influence calculation between personal value sub-variables consists of achievement (X1), stimulation (X2), and self-direction (X3). These subvariables were calculated focusing on the correlation matrix and beta coefficient values. Then, the data were compared to the table value to get the final results. In the end, the final results of the calculation of the correlation matrix are presented in the following table 2.

Table 2. Correlation Matrix Between Dimensions of Personal Value Toward Entrepreneurship Intention

\begin{tabular}{|c|l|l|l|l|}
\hline Variable & \multicolumn{1}{|c|}{$\mathbf{X}_{\mathbf{1}}$} & \multicolumn{1}{|c|}{$\mathbf{X}_{\mathbf{2}}$} & \multicolumn{1}{|c|}{$\mathbf{X}_{\mathbf{3}}$} & \multicolumn{1}{|c|}{} \\
\hline $\boldsymbol{X} \mathbf{1}$ & 1 & 0.270 & 0.207 & 0.311 \\
\hline $\boldsymbol{X} \mathbf{2}$ & 0.270 & 1 & 0.526 & 0.351 \\
\hline $\boldsymbol{X} \mathbf{3}$ & 0.207 & 0.526 & 1 & 0.557 \\
\hline $\boldsymbol{Y}$ & 0.311 & 0.351 & 0.557 & 1 \\
\hline
\end{tabular}

After obtaining the calculated matrix correlation between the dimensions of the personal value toward entrepreneurship intention, then the further calculation was done to determine the $t$ value and the value of the path coefficient of each dimension. The path coefficient value was determined by finding out the value of the beta coefficient using regression analysis in the SPSS 24.0 for the windows program. The scale of the regression calculation between the achievement variable (X1) towards entrepreneurship intention is 0.198 , the scale of the stimulation variable regression value (X2) to entrepreneurship intention is 0.36 , and the results of the calculation of self-direction regression (X3) towards entrepreneurship intention are 0.497.

The value of the table for the number of respondents was 75 with a degree of freedom df (n-2) of 1,993. If the value of $\mathrm{t}$ is greater than the table then the decision making is a rejection of $\mathrm{H} 0$. Based on the calculation results it is known that the value of the $\mathrm{T}$ count for the achievement sub variable is 1,985 because the $T$ count value is smaller than the $\mathrm{T}$ table value, then the decision taken is $\mathrm{HO}$ accepted, meaning that the achievement subvariable (X1) has no positive effect on entrepreneurship intention. T count value on sub variable stimulation (X2) is 0.036 , this value is smaller than the $\mathrm{T}$ table, then the decision is $\mathrm{HO}$ is accepted, that is stimulation does not have a positive effect on entrepreneurship intention. Meanwhile, the t-count value of the self-direction (X3) sub-variable is 4,411 , this value is greater than the value on the table, then the decision taken is $\mathrm{H} 0$ rejected or there is a positive influence between self-direction and entrepreneurship intention.

After knowing the coefficient values of beta and $\mathrm{T}$ count of personal value, the epsilon variable values were calculated with the coefficient of determination. The coefficient of determination in this study has amounted to 0.351 , then performed calculations using the formula to find the epsilon variable obtained $\rho Y \varepsilon=0.805$. This illustrates that for $((0.085) 2 \times 100 \%=64.9 \%) 64.9 \%$ other variables not examined affect the entrepreneurship intention of grade XII students of SMK Kiansantang. Meanwhile, it is simultaneously known that achievement (X1), stimulation (X2), and self-direction (X3) affect entrepreneurial intention by $35.1 \%$. The results of calculations on the correlation matrix and epsilon variables are shown in the path diagram in the analysis path in fig. 2 . follows.

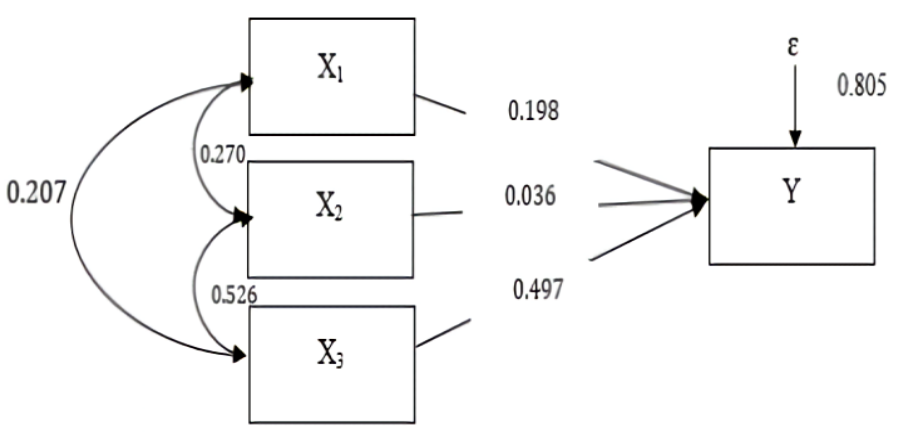

Figure 2 Path diagram

The direct and indirect effects are obtained by multiplying the correlation coefficient with the path coefficient. The results of direct and indirect influences between personal value sub-variables consisting of achievement (X1), stimulation (X2), and self-direction (X3) on entrepreneurship intention are as follows table 3.

Table 3. Results of Direct and Indirect Effects of Personal Value (X) on Entrepreneurship Intention (Y)

\begin{tabular}{|c|c|c|c|c|c|}
\hline $\begin{array}{c}\text { Varia } \\
\text { ble }\end{array}$ & $\begin{array}{c}\text { Path } \\
\text { Coeff } \\
\text { ect }\end{array}$ & $\begin{array}{c}\text { Dire } \\
\text { ct } \\
\text { Effe } \\
\text { ct }\end{array}$ & Indirect Effect & $\begin{array}{c}\text { Total } \\
\text { Indir } \\
\text { ect } \\
\text { Effec } \\
\text { t }\end{array}$ & $\begin{array}{c}\text { Tot } \\
\text { al }\end{array}$ \\
\hline
\end{tabular}




\begin{tabular}{|c|l|l|l|l|l|l|l|}
\hline $\boldsymbol{X} \mathbf{1}$ & 0.198 & 0.03 & 1 & 0.00 & 0.02 & 0.022 & 0.06 \\
& & 92 & & 19 & 03 & 2 & 14 \\
\hline $\boldsymbol{X} \mathbf{2}$ & 0.036 & 0.00 & 0.00 & 1 & 0.00 & 0.011 & 0.01 \\
& & 12 & 19 & & 94 & 3 & 25 \\
\hline $\boldsymbol{X} \mathbf{3}$ & 0.497 & 0.24 & 0.02 & 0.00 & 1 & 0.029 & 0.27 \\
& & 70 & 03 & 94 & & 7 & 67 \\
\hline Total & & & & & & & 0.35 \\
Effect & & & & & & & 06 \\
\hline
\end{tabular}

The table above indicates that the test results of the direct influence of personal value (X) on entrepreneurship intention $(\mathrm{Y})$ show that the most dominant sub-direction variable (X3) is 0.2470 . While the sub-variable that has the least dominant direct effect is the stimulation sub variable of 0.0012 (X2). First, the direct effect of achievement variable (X1) on entrepreneurial intention (Y) of 0.0392. While the indirect effect of achievement sub-variable (X1) through stimulation sub-variable (X2) is 0.0019 , meaning that the stimulation sub-variable and achievement sub-variable can simultaneously reduce the effect of achievement subvariable. The achievement sub variable (X1) has an indirect effect on entrepreneurial intention $(\mathrm{Y})$ through self-direction (X3) of 0.0203 , meaning that the selfdirection sub variable simultaneously with the achievement sub variable can reduce the effect of the achievement sub variable. The total indirect effect of achievement sub-variable (X1) on entrepreneurship intention is 0.0222 .

Second, the direct effect of sub variable stimulation (X2) on entrepreneurship intentions (Y) of 0.0012. While the indirect effect of stimulation sub-variable (X2) through achievement (X1) is 0.0019 , meaning that stimulation sub-variable and achievement sub-variable can simultaneously increase the effect of stimulation subvariable on entrepreneurship intention. Meanwhile, stimulation sub variable (X2) through self-direction sub variable (X3) can simultaneously increase the influence of stimulation sub variable significantly from 0.0012 to 0.0094 . The total indirect effect of sub variable stimulation (X2) on entrepreneurship intention is 0.0113 .

Third, the effect of self-direction (X3) sub variable directly on entrepreneurship intention (Y) of 0.2470. The magnitude of the effect of self-direction (X3) on entrepreneurship intention (Y) through achievement variable (X1) is 0.0203 , meaning that self-direction simultaneously with achievement can reduce the effect of self-direction. Meanwhile, the influence of sub-variable self-direction (X3) through stimulation (X2) is 0.0094 , meaning that simultaneously self-direction and stimulation can reduce the influence of self-direction.

Based on the description above it can be seen that the variable of personal value that has the most dominant influence both directly and indirectly on entrepreneurship intention is the self-direction variable. The self-direction variable can indirectly increase the effect of the two other personal value variables, namely, achievement and stimulation on entrepreneurship intention. While the achievement variable and stimulation variable can reduce the effect of other variables on entrepreneurship intention. Judging from the coefficient of determination between the variables of personal value to entrepreneurship intention of 0.351 , which is interpreted against the influence table Guildford in [23] included in the weak category.

\section{CONCLUSIONS}

The results of research on the influence of personal value on entrepreneurship intention simultaneously positive and significant effect. While based on the calculation of each personal value variable on entrepreneurship intention, directly and indirectly, it is known that for achievement variable, stimulation and self-direction variables can weaken its influence on entrepreneurship intention. As for the stimulation variable, achievement variable \& self-direction variable can increase their influence on entrepreneurship intention. Meanwhile, the self-direction variable becomes weak if it is examined simultaneously with the achievement variable and the stimulation variable. The self-direction variable is the variable that has a dominant direct effect on entrepreneurship intention. While the variable that is the least dominant influence on entrepreneurship intention is the stimulation variable.

Empirically, the results of the simultaneous study of personal values towards entrepreneurship intention in XII grade SMK Kiansantang have a low significance value. Researchers provide recommendations for further research on entrepreneurship intention by using different theories. One theory that the authors recommend is the entrepreneurial mindset which is a continuation of the process of realization of personal value.

\section{REFERENCES}

[1] Winardi, Entrepreneur dan entrepreneurship. Jakarta: Kencana, 2008.

[2] McKinsey\&Company, "Automation and the future of work in indonesia," McKinsey Co., no. September, pp. 21-28, 2019, [Online]. Available: https://www.mckinsey.com/ /media/McKinsey/Fe atured Insights/Asia Pacific/Automation and the future of work in Indonesia/Automation-and-thefuture-of-work-in-Indonesia-vF.ashx.

[3] I. P. Thahara, H. Mulyadi, and D. H. Utama, "Efektivitas model problem based learning dalam meningkatkan kemampuan berpikir kritis peserta didik pada kelas bisnis dan kewirausahaan," J. Bus. Manag. Educ., vol. 1, no. 2, 2017, doi: 10.17509/jbme.v1i2.5966. 
[4] "Produk Kreatif dan Kewirausahaan (PKKWU) and digital communication simulation." Kemendikbud.go.id (accessed Nov. 13, 2019).

[5] Khurniawan, M. A. W., Rivai, and Turijin, "Pengembangan kewirausahaan smk: profil pelaku usaha mikro kecil dan menengah (UMKM di Indonesia), 2019.

[6] F.-L. T. Yu and F.-L. T. Yu, "The entrepreneurial process," in New perspectives on economic development, 2011.

[7] D. McClleland, "Characteristics of Successful Entrepreneurs," J. or Creat. Behav., vol. 21, no. 3, pp. 219-233, 1986.

[8] B. Alma, Manajemen Pemasaran dan Pemasaran Jasa Cetakan 5. Bandung: CV Alfabeta. 2011.

[9] W. Bygrave and A. Zacharakis, Entrepreneurship (2nd Edition). John WIley \& Sons, Inc., 2011.

[10] S. H. Schwartz, "Basic individual values: sources and consequences," in Handbook of Value, 2015.

[11]D. Gursoy, L. Altinay, and A. Kenebayeva, "Religiosity and entrepreneurship behaviours," Int. J. Hosp. Manag., vol. 67, no. August, pp. 87-94, 2017, doi: 10.1016/j.ijhm.2017.08.005.

[12] R. M. Amir, B. Burhanuddin, and W. B. Priatna, "The effect of individual, environmental and entrepreneurial behavior factors on business performance of cassava smes agroindustry in padang city," Indones. J. Bus. Entrep., 2018, doi: 10.17358/ijbe.4.1.1.

[13] L. Bima, R. Nurbani, R. Diningrat, C. Marlina, E. Hermanus, and S. Lubis, "Urban child poverty and disparity: the unheard voices of children living in poverty in indonesia," 2017.

[14] N. Bosma, J. Hessels, V. Schutjens, M. Van Praag, and I. Verheul, "Entrepreneurship and role models," J. Econ. Psychol., vol. 33, no. 2, 2012, doi: 10.1016/j.joep.2011.03.004.

[15] T. Krisnawati and I. Mahaendra Yasa, "Pengaruh variabel ekonomi dan sosial demografi terhadap status ekonomi perempuan di kabupaten jembrana," Bul. Stud. Ekon., vol. 21, no. 1, 2016.

[16]B. Verplanken and R. W. Holland, "Motivated decision making: effects of activation and selfcentrality of values on choices and behavior," $J$. Pers. Soc. Psychol., vol. 82, no. 3, pp. 434-447, 2002, doi: 10.1037/0022-3514.82.3.434.

[17] M. J. Gorgievski, U. Stephan, M. Laguna, and J. A. Moriano, "Predicting entrepreneurial career intentions: values and the theory of planned behavior," J. Career Assess., vol. 26, no. 3, 2018, doi: 10.1177/1069072717714541.

[18] I. Jaén, J. A. Moriano, and F. Liñán, "Personal values and entrepreneurial intention: An empirical study," Concept. Richness Methodol. Divers. Entrep. Res., pp. 15-31, 2013, doi: $10.4337 / 9781782547310.00008$.

[19] S. Arikunto, "Prosedur penelitian pendidikan suatu pendekatan praktik," Jakarta: Rineka Cipta, 2010.

[20] Notoatmodjo, "Metodologi penelitian kesehatan. Jakarta: Rineka Cipta.," Notoatmodjo, S. (2018). Metodol. Penelit. Kesehatan. Jakarta Rineka Cipta., vol. 4, no. 12, 2018.

[21] Kusnendi, Model-model persamaan struktural stu dan multigroup sampai dengan lisrel. Bandung: Alfabeta, 2008.

[22] Prof. Dr. Sugiyono, Metode penelitian kombinasi (mixed metods). 2012.

[23] Sugiyono, "Metode penelitian bisnis. Bandung: CV. Alfabeta.," Metod. Penelit. Bisnis., vol. 129, 2009. 